\title{
In vitro Fluoride Release and Tensile Bond Strength of a Polymeric Intra-Buccal Bioadhesive
}

\author{
Liberación in vitro de Flúor y Fuerza de Tracción \\ de un Bioadhesivo Polimérico Intra-Bucal
}

"Vinícius Pedrazzi; **Elza Helena Guimarães Lara; *Heitor Panzeri; ***John H. Collett \& “João Paulo Mardegan Issa

\begin{abstract}
PEDRAZZI, V.; LARA, E. H. G.; PANZERI, H.; COlletT, J. H. \& ISSA, J. P. M. In vitro fluoride release and tensile bond strength of a polymeric intra-buccal bioadhesive. Int. J. Morphol., 27(3):801-803, 2009.

SUMMARY: The intra-buccal polymeric bioadhesive systems that can stay adhered to the oral soft tissues for drug programmed release, with the preventive and/or therapeutic purpose has been employed for large clinical situations. A system based on hydroxypropyl methyl cellulose/Carbopol 934\%/magnesium stearate ( $\mathrm{HPMC} / \mathrm{Cp} / \mathrm{StMg})$ was developed having the sodium fluoride as active principle. This kind of system was evaluated according to its resistance to the removal by means of physical test of tensile strength. Swine buccal mucosa extracted immediately after animals' sacrifice was employed as substrate for the physical trials, to obtain 16 test bodies. Artificial saliva with or without mucin was used to involve the substrate/bioadhesive system sets during the trials. Artificial salivas viscosity was determined by means of Brookfield viscometer, showing the artificial saliva with mucin $10.0 \mathrm{cP}$, and the artificial saliva without mucin $7.5 \mathrm{cP}$. The tensile strength assays showed the following averages: for the group "artificial saliva with mucin" - $12.89 \mathrm{~Pa}$, and for the group "without mucin" - 12.35 Pa. Statistical analysis showed no significant difference between the assays for both artificial salivas, and it was possible to conclude that the variable mucin did not interfered with the bioadhesion process for the polymeric devices. The device was able to release fluoride in a safe, efficient and constant way up to 8 hours.
\end{abstract}

KEY WORDS: Drug delivery systems; Oral delivery; Mucin; Oral mucosa, Fluoride.

\section{INTRODUCTION}

Since the primordials of the human civilization, some kind of drugs has always been employed for the relief and/ or healing of diseases, and the oral path was the most suitable and used way of direction (Polli et al., 2008). Although, its employ as a large route for polymeric systems drugs delivery (Squier \& Wertz, 1996), the adhesive properties of oral mucosa, and drug release ability from polymeric systems, are still under continuous investigation (Senel et al., 2001). Some authors (Peppas \& Sahlin, 1996) given to the mucin an important role in the bioadhesion process, but many others inquirers (Needleman \& Smales, 1995) achieved that the absence of mucin improved the tensile bond strength of polymeric devices at the oral mucosa. By other hand, the recent knowledge showed that the fluoride preventive employment is more efficient by using small and constant amounts in the oral cavity.

\section{MATERIAL AND METHOD}

This paper is designed to trial a new format of an intra-buccal polymeric device, using artificial saliva with or without mucin. The polymeric device used in this work (modified from Garcia et al., 1998), was obtained employing HPMC (hydroxypropyl metyl cellulose) + Cp (Carbopol $\left.934^{\mathrm{TM}}\right)+\mathrm{StMg}$ (magnesiun stearate) and $\mathrm{NaF}$ (sodium fluoride) as an active compound. A hydraulic press machine model C/12 (Fred S. Carver Inc.), with 5.5mm punction, was employed to obtain the polymeric devices, with 1.5 tons compression. An illustration of the 3 layers device is shown in Figure 1.

Swine buccal mucosa was chosen as a substrate for the tensile bond strength, because its anatomical and physiological characteristics are similar to the human ones delivery (Squier \& Wertz). Pieces of recently sacrificed swine

\footnotetext{
* Ribeirão Preto Faculty of Dentistry, University of São Paulo, São Paulo, Brazil.

** Ribeirão Preto Faculty of Pharmacy, University of São Paulo, São Paulo, Brazil.

${ }^{* * * *}$ Faculty of Pharmacy, University of Manchester, Manchester, United Kingdon.
} 


\section{UPper [HPMC/Cp-(1:2) physical mixtune + SAMg] - \{isolating layer\} \\ 2. Internedinte [NaF $-1 \mathrm{mg}+\mathrm{HPMC} / \mathrm{Cp}-(1-2)]$ physical mix ture \{release layer \\ 3. Lower [HPMC/Cp-(1:2) lyophylized mixture \{adhesive layer\}}

Fig. 1. The 3-layers polymeric device designed to release fluoride.

were surgically removed and stored in a Bio-Freezer at $70^{\circ} \mathrm{C}$ (Bouckaert \& Remon, 1993.) until the moment of the assays. Each of the 16 obtained pieces was fixed to plexglass thin plates with cianoacrylate adhesive. The polymeric devices were also fixed with cianoacrylate adhesive to metal holders, and the obtained sets were put in contact by finger pressure, for $5 \mathrm{~min}$, until the adhesion.

For the tensile bond strength, it was employed an equipment similar to the recommended in bulletin ISO (ISO -Dental materials: guidance on testing of adhesion to tooth structure, 1994), with a $50 \mathrm{kgf}$ load cell, and at $50 \pm 2 \mathrm{~N} / \mathrm{min}$ speed. Artificial saliva with (Vissink et al., 1985) or without mucin (Nakamoto, 1979) was employed as a tested medium during the trials for to verify mucin influence in adhesion process. Additionally, the viscosity of both artificial salivas was measured using a Brookfield viscosimeter at environment temperature $\left(25^{\circ} \mathrm{C}\right)$. Fluoride release from the polymeric device was assessed "in vitro" employing an apparatus modified from Ishida et al. (1982) and a specific electrode for the fluoride measurement, according to the methodology developed by Spadaro et al. (2001).

\section{RESULTS AND DISCUSSION}

The tensile bond strength data obtained with the polymeric devices are shown in Table I. Due to the homogenicity of the variances (F Test: $F=2.05$; $p$-value $=$ 0.37 ) of the data obtained from the trials regarding the upkeep medium, they were analyzed by t-student test. The saliva samples viscosity is shown in the Table II.

The results of the tensile bond strength physical trials are compatibles with those already published in the scientific literature (average of 4.7), despite the load cell employed for this work $(50 \mathrm{~N})$ being less sensitive than the one in the literature $(20 \mathrm{~N})$, assuming the same or a superior behaviour in our assays. Although, the artificial saliva with mucin is more viscous than the one without mucin (25\% less viscous), the t-student test showed that the variable mucin did not interfered in the bioadhesion of the polymeric devices at this investigation. The polymeric device showed to be able to stay adhered to the mucosa releasing fluoride in a safe, efficient and constant way up to 8 hours (Table III).

Table I. Tensile Bond Strength Trials. Where: MAS= artificial saliva with mucin; WAS= artificial saliva without mucin.

\begin{tabular}{lccccccccr}
\hline Mediums & \multicolumn{8}{c}{ Tensile gauge $(\mathrm{Pa})-$ total of 16 test bodies } \\
MAS & 8.2 & 16.5 & 8.2 & 12.4 & 12.4 & 16.5 & 16.5 & 12.4 & 12.89 \\
WAS & 8.2 & 8.2 & 16.5 & 16.5 & 12.4 & 8.2 & 8.2 & 20.6 & 12.35 \\
\hline
\end{tabular}

Table II. Viscosity $(\mathrm{cP})$ of the saliva samples (distilled water $=$ pattern).

\begin{tabular}{lccc}
\hline Spindle x Speed & MAS & SAS & Water \\
\hline S1V10 & 10.0 & 7.5 & 1.0 \\
\hline
\end{tabular}

Table III. The "in vitro" Fluoride released from the polymeric device in ppmF (during 8 hours). *Mean value $(\mathrm{n}=3) \pm$ pattern deviation.

\begin{tabular}{cccc}
\hline Time $(\mathrm{h})$ & Fluoride released $(\mathrm{ppmF})$ & Total Fluoride released $(\mathrm{ppmF})$ & Concentration $(\mu \mathrm{g} / \mathrm{h})$ \\
\hline 1 & $3.45^{*} \pm 0.15$ & 3.45 & 86.25 \\
3 & $2.10 \pm 0.10$ & 8.35 & 52.50 \\
5 & $1.40 \pm 0.08$ & 11.67 & 35.00 \\
7 & $0.88 \pm 0.02$ & 13.55 & 22.00 \\
8 & $0.87 \pm 0.02$ & 14.42 & 21.75 \\
\hline
\end{tabular}


PEDRAZZI, V.; LARA, E. H. G.; PANZERI, H.; COLleTT, J. H. \& ISSA, J. P. M. Liberación in vitro de de flúor y fuerza de tracción de un bioadhesivo polimérico intra-bucal. Int. J. Morphol., 27(3):801-803, 2009.

RESUMEN: Los sistemas bioadhesivos poliméricos intra-bucales pueden permanecer adheridos a los tejidos blandos orales para una liberación programada de fármacos, con finalidad preventiva y/o propósito terapéutico han sido empleados en diversas situaciones clínicas. Un sistema basado en Hidroxipropilmetilcelulosa/Carbopol934Ô/ estearato de magnesio (HPMC/Cp/StMg) fue desarrollado con fluorato de sodio como principio activo. Este tipo de sistema fue evaluado de acuerdo a su resistencia a la eliminación física por medio de pruebas de resistencia a la tracción. Mucosas bucales de cerdos fueron tomadas inmediatamente después del sacrificio de los animales y se utilizaron como sustrato para las pruebas físicas, obteniendo 16 cuerpos de prueba. Saliva artificial con o sin mucina fue utilizada para participar como parte del sistema sustrato/bioadesivo durante los ensayos. La viscosidad de la saliva artificial, se determinó mediante un viscosímetro Brookfield, mostrando la saliva artificial con mucina 10,0 cP y saliva artificial sin mucina 7,5 cP. Las pruebas de resistencia a la tracción mostraron los siguientes promedios: para la "saliva artificial con mucina" - 12,89 Pa, y para el grupo "sin mucina" - 12,35 Pa. El análisis estadístico no mostró diferencias significativas entre las pruebas de saliva artificial, y es posible concluir que la variable de mucina no interfiere con el proceso de bioadhesión del dispositivo polimérico. El dispositivo fue capaz de liberar fluor de forma segura, eficiente y constante durante un máximo de hasta 8 horas.

PALABRAS CLAVE: Sistemas de liberación de medicamentos; Liberación oral; Mucina; Mucosa oral; Fluor.

\section{REFERENCES}

Bouckaert, S. \& Remon, J. P. In vitro bioadhesion of a buccal, miconazole slow-release tablet. J. Pharm. Pharmacol., 45:504-7, 1993.

Garcia, A. L.; Lara, E. H. G. \& Panzeri, H. Estudo in vitro de sistemas bioadesivos para a liberação sustentada de fluoreto. Rev. Odontol. Univ. São Paulo., 12:143-8, 1998.

Ishida, M.; Nambu, N. \& Nagai, T. Mucosal dosage form of lidocaine for toothache using hidroxypropil cellulose and carbopol. Chem. Pharm. Bull., 30:980-4, 1982.

ISO. Dental materials: guidance on testing of adhesion to tooth structure. Genéve, Technical Report, 11405, 1994.

Nakamoto, R. Y. Use of saliva substitute in post-radiation xerostomia. J. Prosthet. Dent., 42:539-42, 1979.

Needleman, I. G. \& Smales, F. C. In vitro assessment of bioadhesion for periodontal and buccal drug delivery. Biomaterials, 16:617-24, 1995.

Peppas, N. A. \& Sahlin, J. J. Hydrogel as mucoadhesive and bioadhesive materials: a review. Biomaterials, 17:155361, 1996.

Polli, J. E.; Abrahamsson, B. S.; Yu, L. X.; Amidon, G. L.; Baldoni, J. M.; Cook, J. A.; Fackler, P.; Hartauer, K.; Johnston, G.; Krill, S. L.; Lipper, R. A.; Malick, W. A.; Shah, V. P., Sun, D.; Winkle, H. N.; Wu, Y. \& Zhang, H. Summary workshop report: bioequivalence, biopharmaceutics classification system, and beyond. AAPS J., 10:373-9, 2008.
Senel, S.; Kremer, M.; Nagy, K. \& Squier, C. Delivery of bioactive peptides and proteins across oral (buccal) mucosa. Curr. Pharm. Biotechnol., 2:175-86, 2001.

Spadaro, A. C.; Leitão, D. P.; Polizello, A. C.; Pedrazzi, V. \& Mestriner Júnior, W. Construction and evaluation of an inexpensive device that simulates oral clearance. Braz. Dent. J., 12:183-6, 2001.

Squier, C. A. \& Wertz, P. W. Structure and function of the oral mucosa and implications for drug delivery. In: Rathbone, M. J. (ed.). Oral mucosal drug delivery. New Zealand, Marcel Dekker, 1996. pp.1-26.

Vissink, A.; Gravenmade, E. J.; Gelhard, T. B. F. M.; Panders, K. \& Franken, M. H. Rehardening properties of mucinor CMC-containing saliva substitutes on softened human enamel. Caries Res., 19:212-8, 1985.

Correspondence to:

Prof. Dr. Vinícius Pedrazzi

Faculdade de Odontologia de Ribeirão Preto

Universidade de São Paulo- USP

Departamento de Materiais Dentários e Prótese

Av. Café S/N, Monte Alegre

CEP 14040-904

Ribeirão Preto- SP

BRASIL

Tel: +55-16-36024008, Fax: +55-16-36330999

E-mail: pedrazzi@forp.usp.br

Received: 09-01-2009

Accepted: 03-03-2009 
